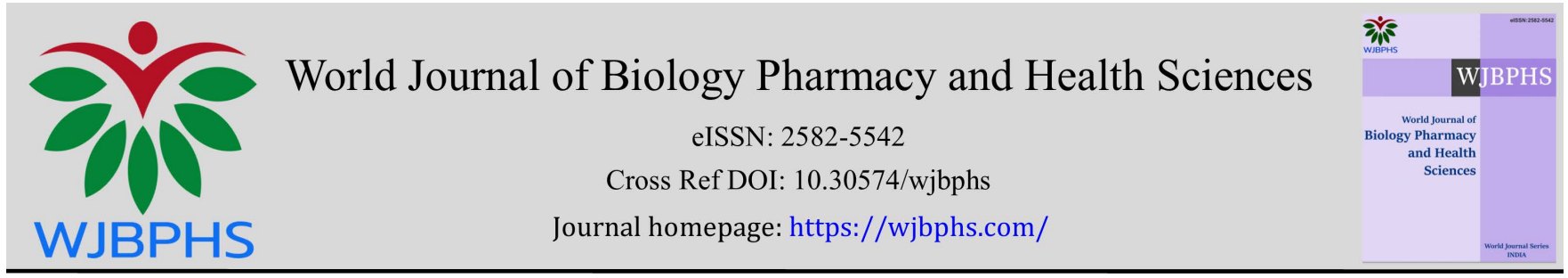

(RESEARCH ARTICLE)

\title{
In vitro antioxidant activity and in vivo aphrodisiac activity in male Cavia porcellus of Albizia adianthifolia (Schum.) W. Wight and Pericopsis angolensis (Baker) Meeuwen
}

Alombong Alonie Gracia 1, Bashige Chiribagula Valentin 1, 2, ${ }^{*}$, Manya Mboni Henry 1, 2, Kamwimba Mahungala Arlette ${ }^{2}$, Bakari Amuri Salvius ${ }^{2}$ and Okusa Ndjolo philippe ${ }^{1}$

${ }^{1}$ Therapeutic Chemistry Laboratory -Faculty of Pharmaceutical Sciences - University of Lubumbashi - 27, av Kato, Municipality of Kampemba, Lubumbashi -DR Congo.

${ }^{2}$ Pharmacognosy Laboratory - Faculty of Pharmaceutical Sciences - University of Lubumbashi - 27, av Kato, Municipality of Kampemba, Lubumbashi -DR Congo.

World Journal of Biology Pharmacy and Health Sciences, 2021, 05(03), 044-052

Publication history: Received on 04 February 2021; revised on 06 March 2021; accepted on 09 March 2021

Article DOI: https://doi.org/10.30574/wjbphs.2021.5.3.0024

\begin{abstract}
This study was carried out to evaluate the aphrodisiac and antioxidant activities of aqueous and methanolic extracts of two plants used as aphrodisiac in traditional medicine in Kampemba municipality, in Lubumbashi DR Congo. Aqueous and methanolic root bark extracts of both Albizia adianthifolia and Pericopsis angolensis were administered orally to male Cavia porcellus before evaluating their physical behavior in the presence of females and their testosterone, cholesterol and triglyceride contents. The antioxidant activity was determined by the DPPH method. At 200 and 250 mg $\mathrm{kg}^{-1}$ body weight (bw), the extracts exhibited a decrease in rise time and intromission time and an increase in ejaculation time, ascending frequency, intromission frequency, ejaculation frequency and testosterone compared to the control group that received sildenafil $\left(10 \mathrm{mg} \mathrm{kg}^{-1} \mathrm{bw}\right)$ used as a reference. A positive relationship between testosterone level and antioxidant activity has also been observed. The aphrodisiac and antioxidant activity observed in the two species justify their uses in traditional medicine as aphrodisiacs. Further work is needed in order to proceed to the isolation and the identification of the active compounds.
\end{abstract}

Keywords: Erectile dysfunction; Congolese traditional medicine; Kampemba; DPPH-test; Fabaceae.

\section{Introduction}

Erectile dysfunction (ED) refers to the constant inability of a man to achieve or maintain an erection for satisfactory sexual activity [1]. The prevalence and severity of ED increases with age [2] and not only affects the life expectancy, but also the well-being and quality of life of exposed people [3]. In the past, plants called aphrodisiacs, in memory of Aphrodite, the Greek god of love, such as Pausinystalia johimbe (K. Schum.) Pierre, Rubiaceae [4] or Zingiber officinalis L, Zingiberaceae [5], have been used to improve sexual pleasure. Several plants are still used today as aphrodisiacs in several cultures.

In Lubumbashi, Albizia adianthifolia (Schum.) W. Wight (Fabaceae), [Synonyms: Albizia fastigiata (E.Mey.) Oliv. Albizia intermedia De Wild. \& T. Durand, Albizia ealaensis De Wild., Albizia gummifera auct. non (JFGmel.) CASm.] and, Pericopsis angolensis (Baker) Meeuwen (Fabaceae), [synonym: Afrormosia angolensis (Baker) Harms.], are two plants widely used in traditional medicine in the treatment of sexual dysfunction in the Kampemba municipality in DR Congo. Albizia adianthifolia is also used as a purgative and antidiabetic as well as in eye, gastrointestinal, hemorrhoidal, cephalic,

\footnotetext{
${ }^{*}$ Corresponding author: Bashige Chiribagula Valentin

Department of Therapeutic Chemistry-Faculty of Pharmaceutical Sciences - University of Lubumbashi - 27, av Kato, Municipality of Kampemba, Lubumbashi -DR Congo.
}

Copyright (c) 2021 Author(s) retain the copyright of this article. This article is published under the terms of the Creative Commons Attribution Liscense 4.0. 
neurodegenerative diseases [6, 7]. A part from ED, Pericopsis angolensis is also used in traditional medicine in respiratory and eye conditions and in gastrointestinal disorders [8].

This study aimed to evaluate the aphrodisiac and antioxidant activities of these two plants, thus contributing to the scientific validation of this aphrodisiac use which they enjoy in the city of Lubumbashi.

\section{Material and methods}

\subsection{Plant material}

The root bark of Albizia adianthifolia and Pericopsis angolensis were collected at Kashamata (south part of Lubumbashi town) in November 2017 respectively at GPS data: alt. $1226 \mathrm{~m}$, south latitude $11^{\circ} 41^{\prime} 57^{\prime \prime}$, longitude $27^{\circ} 42^{\prime} 32^{\prime \prime}$ East and alt. $1201 \mathrm{~m}$, South latitude $11^{\circ} 34^{\prime} 20.1^{\prime \prime}$, East longitude $27^{\circ} 23^{\prime} 32.6^{\prime \prime}$, then identified at the Kipopo herbarium under the respective numbers KIP0011123 and KIP0011124.

\subsection{Experimental animals}

A local strain of Cavia porcellus L. on average weight $380.38 \pm 10.9 \mathrm{~g}$ of both sexes was obtained from the Faculty of Agronomic Sciences of the University of Lubumbashi. These animals were fed with a standard diet (MIDEMA / RD Congo) and acclimatized for 10 days under the experimental environmental conditions $\left(28{ }^{\circ} \mathrm{C}\right.$, alternating light dark every $12 \mathrm{~h}$, meal and water at will).

\subsection{Preparation of extracts and determination of experimental doses}

The methanolic extract (ME) was prepared by maceration of $350 \mathrm{~g}$ of crushed dried plant material in $1.5 \mathrm{~L}$ of methanol (67-56-1 Sigma Aldrich, Belgium) for $48 \mathrm{~h}$. The aqueous extracts (EA) were prepared according to the protocol used in traditional medicine by decoction for 30 minutes of $600 \mathrm{~g}$ of plant material in $4 \mathrm{~L}$ of water for $A$. adianthifolia and by decoction of $750 \mathrm{~g}$ of plant material in $2.5 \mathrm{~L}$ of water for 45 minutes for $P$. angolensis. The macerated or decocted solutions were filtrated under filter paper $(\varnothing=0.25 \mu \mathrm{m}$, No. 1172.000002.05 Whatman, USA), and were evaporated under a rotary evaporator (Büchi R-210, Switzerland). The doses administered in Guinea pigs (Table 1) were deduced from the doses administered in traditional medicine in humans by applying the formula:

$$
\mathrm{D}_{\mathrm{H}}=\frac{K m A}{K m H} x D_{A}[9] \text {. }
$$

With $\mathrm{D}_{\mathrm{H}}=$ Dose in humans (in mg.kg-1); $\mathrm{D}_{\mathrm{A}}=$ Dose in animals (in mg. $\mathrm{kg}^{-1}$ ); $\mathrm{KmH}=$ Body surface constant in humans of $70 \mathrm{~kg}=37 \mathrm{mg} .\left(\mathrm{m}^{2}\right)^{-1}, \mathrm{KmA}=$ body surface consistency in Cavia porcellus of $\left.0.4 \mathrm{~g}=8 \mathrm{mg} .\left(\mathrm{m}^{2}\right)^{-1}\right)$.

Table 1 Determination of the experimental dose in humans versus in Cavia porcellus.

\begin{tabular}{|l|l|c|c|c|c|}
\hline Plants & $\begin{array}{l}\text { Extract used in traditional } \\
\text { medicine }\end{array}$ & $\begin{array}{c}\text { EB } \\
\text { (g) }\end{array}$ & $\begin{array}{c}\text { D } \\
\text { (mg / kg) }\end{array}$ & $\begin{array}{c}\text { D } \\
\text { (mg / kg) }\end{array}$ & $\begin{array}{c}\text { Adjusted dose } \\
\text { (mg/kg) }\end{array}$ \\
\hline P. Angolensis & $\begin{array}{l}\text { Decoction of 2 handfuls of } \\
\text { root bark powder in 2L of } \\
\text { water for 30 minutes. Drink 2 } \\
\text { cups 1 hour before the act. }\end{array}$ & $3.01 \pm 0.2$ & $42.9 \pm 0.2$ & $198.4 \pm 0.2$ & 200 \\
\hline $\begin{array}{l}\text { Decoction of 2 and a half } \\
\text { handfuls of root bark powder } \\
\text { for 45 minutes in 2.5 L of } \\
\text { water, drink a cup 1 hour } \\
\text { before the act. }\end{array}$ & $3.71 \pm 0.1$ & $52.9 \pm 0.1$ & $244.7 \pm 0.1$ & 250 \\
\hline Sildenafil & NA & N A & 1.43 & 6.6 & 10 \\
\hline
\end{tabular}

1 handful $=28 \mathrm{~g}$ for $A$. adianthifolia and $35 \mathrm{~g}$ for $P$. angolensis, 1 cup $=450 \mathrm{~mL} \mathrm{D}_{\mathrm{H}}=\mathrm{EB} * 100 / 7$, the results are expressed as the mean \pm standard deviation of 3 repetitions. $\mathrm{D}_{\mathrm{A}}=$ dose administered in animals, $\mathrm{D}_{\mathrm{H}}$ : dose administered in humans; EB: crude extract; NA: not applicable. 


\subsection{Aphrodisiac activity assessment}

The aphrodisiac activity evaluation test was inspired by a previous protocol [10]. Briefly, fifty male Cavia porcellus were randomized into 10 groups (GA) of 5 animals each. The animals of group A, which served as control, received per $2 \mathrm{~mL}$

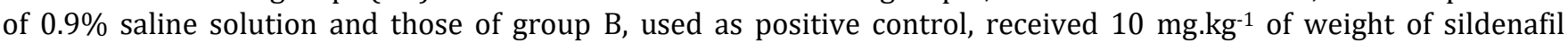
(MFCD09026931; Sigma-Aldrich, UK). Animals of groups C, D, (aqueous extract) E, F (methanolic extracts), for $A$. adianthifolia, and G, H (aqueous extract), I, J (methanolic extract) for P. angiogenesis, were treated with 200 and 250 mg. $\mathrm{kg}^{-1}$ of extract. All the administrations were carried out in a single dose at 8:00 am by gavage probe and 45 minutes after administration, the female Cavia porcellus were introduced into metal cages ( $0.5 \mathrm{~m} \times 0.5 \mathrm{~m} \times 0.5 \mathrm{~m})$ where male Cavia porcellus were monitored for $2 \mathrm{~h}$ using a camera (SONY FDR-AX53 HANDYCAM 4K). The sexual behavior of male Cavia porcellus based on physical parameters including rise time (RT), intromission time (IT), ejaculation time (ET), postejaculatory interval (PEI), number of displays (ND), the number of intromissions (NI) and the number of ejaculations (NE) as well as the measurements of biochemical parameters such as total cholesterol, triglyceride and testosterone concentration were used to evaluate the aphrodisiac activity. The assays were carried out as described in the Total cholesterol assay kit (STA-38, CellBiolabs.inc.), Triglyceride Colorimetric Assay Kit (No. 10010303, Cayman) and Testosterone ELISA Kit (KA0309, Abnova), at the university clinics of Lubumbashi.

\subsection{Antioxidant activity evaluation}

Antioxidant activity was evaluated using the DPPH method developed previously [11]. Briefly, $50 \mu \mathrm{L}$ of extract or ascorbic acid, positive control, prepared at different dilutions in methanol from a $100 \mu \mathrm{g} / \mathrm{mL}$ solution were interacted with $1950 \mu \mathrm{L}$ of DPPH ( 0.002\% in a 96-well plate (Nunc WVR, Germany). After mixing and incubating in the darkness for 30 minutes, the solution was read in a spectrophotometer (Thermo Fisher Scientific Inc., Waltham, USA) at $492 \mathrm{~nm}$. The tests were performed in triplicate and the $0.002 \%$ DPPH solution was used as a negative control. The percentage of antioxidant activity was calculated by the formula: $\mathrm{I}(\%)=(\mathrm{Ab}-\mathrm{Ae}) \times 100 \times \mathrm{Ab}^{-1}$ with $\mathrm{Ab}=\mathrm{absorbance}$ measured in the presence of the negative control; $\mathrm{Ae}=$ absorbance measured in the presence of the extract, I $(\%)=$ Percentage of inhibition. This percentage of activity allowed to generate $\mathrm{IC}_{50}$.

\subsection{Statistical analysis of data}

Statistical analysis of the data was made possible using GraphPad Prism version 6 software (GraphPad Software, La Jolla, USA). The comparison between two means was carried out by Student's t test and that of several variables by oneway ANOVA, the significance level was set at $95 \%$.

\section{Results}

\subsection{Aphrodisiac activity}

\subsubsection{Physical parameters of sexual behavior}

The different physical parameters vary significantly compared to the negative control group (with a $\mathrm{p}<0.01$ ). Declines are recorded for RT, IT and PEI unlike ET, ND, NI and NE which increased. At equal doses, Albizia adianthifolia (A. adianthifolia) exhibits more expressive performance indicators than Pericopsis angolensis (P. angolensis). The EM of $A$. adianthifolia seem more efficient than the EA unlike $P$. angolensis where the performances between the two extracts (EA and EM) seem to be of the same amplitude. A. adianthifolia at $200 \mathrm{mg} . \mathrm{kg}^{-1}$ and $P$. angolensis at $250 \mathrm{mg} . \mathrm{kg}^{-1} \mathrm{exhibit}$ better physical parameters than Sildenafil, used as a positive control (Table 2). The rise time (RT) of the extracts varies

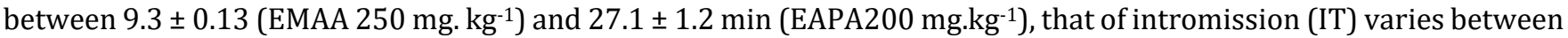
$0.38 \pm 0.13$ (EMAA250 mg. $\mathrm{kg}^{-1}$ ) and 5, $1 \pm 0.13$ (EMPA $200 \mathrm{mg}^{\mathrm{kg}} \mathrm{kg}^{-1}$ ) min and that of ejaculation (ET) varies between $1.5 \pm 0.11$ (EAPA200 mg. $\mathrm{kg}^{-1}$ ) and $3.6 \pm 0.13$ (EAAA200 mg. kg-1). The post-ejaculatory interval (PEI) varies between $0.30 \pm 0.10$ (EM AA $200 \mathrm{mg}$. kg-1) and $11.5 \pm 2.13$ (EMPA $200 \mathrm{mg}$. kg-1). Except for PA $250 \mathrm{mg}^{-1} \mathrm{~kg}^{-1}$, RT is lower in the methanolic extract than the aqueous extract and overall a very significant drop in TM is observed in comparison with the negative control group. With the exception of $P$. angolensis $200 \mathrm{mg}$. $\mathrm{kg}^{-1}$, the extracts show a lower RT compared to the positive control group $(\mathrm{p}<0.01)$ (Table 2). 
Table 2 Variation of physical parameters during the evaluation of aphrodisiac activity.

\begin{tabular}{|c|c|c|c|c|}
\hline Groups & RT (min) & IT (min) & ET (min) & PEI (min) \\
\hline NaCl 0.9 \% & $57.7 \pm 1.5$ & $6.47 \pm 0.0$ & $0.45 \pm 0.11$ & $20.4 \pm 0.13$ \\
\hline Sildenafil10mg.kg-1 & $15.3 \pm 2.3^{\mathrm{d}}$ & $2.41 \pm 0.6^{\mathrm{d}}$ & $2.6 \pm 0.13^{\mathrm{b}}$ & $0.57 \pm 0.13^{\mathrm{d}}$ \\
\hline EAAA 200 $\mathrm{mg} \mathrm{kg}^{-1}$ & $12.3 \pm 1.7^{\mathrm{d}}$ & $2.3 \pm 0.3^{\mathrm{d}}$ & $3.6 \pm 0.13^{\mathrm{d}}$ & $0.45 \pm 0.01^{\mathrm{d}}$ \\
\hline EMAA 200 $\mathrm{mg} \mathrm{kg}^{-1}$ & $10.1 \pm 0.11^{\mathrm{d}}$ & $0.42 \pm 0.11^{\mathrm{d}}$ & $1.8 \pm 0.14^{\mathrm{a}}$ & $0.30 \pm 0.10^{\mathrm{d}}$ \\
\hline EAAA 250 $\mathrm{mg} \mathrm{kg}^{-1}$ & $13.1 \pm 0.13^{\mathrm{d}}$ & $2.7 \pm 0.11^{\mathrm{d}}$ & $3.4 \pm 0.13^{\mathrm{d}}$ & $0.51 \pm 0.13^{\mathrm{d}}$ \\
\hline EMAA 250 $\mathrm{mg} \mathrm{kg}^{-1}$ & $9.3 \pm 0.13^{\mathrm{d}}$ & $0.38 \pm 0.13^{\mathrm{d}}$ & $1.5 \pm 0.13^{\mathrm{a}}$ & $0.49 \pm 0.13^{\mathrm{d}}$ \\
\hline EAPA 200 $\mathrm{mg} \mathrm{kg}^{-1}$ & $27.1 \pm 1.2^{\mathrm{d}}$ & $3.1 \pm 0.20^{\mathrm{d}}$ & $1.5 \pm 0.11^{\mathrm{a}}$ & $10.4 \pm 1.10^{\mathrm{d}}$ \\
\hline EMPA 200 $\mathrm{mg} \mathrm{kg}^{-1}$ & $20.2 \pm 0.13^{\mathrm{d}}$ & $5.1 \pm 0.13^{\mathrm{c}}$ & $4.1 \pm 0.13^{\mathrm{d}}$ & $11.5 \pm 2.13^{\mathrm{d}}$ \\
\hline EAPA 250 $\mathrm{mg} \mathrm{kg-1}^{-1}$ & $12.1 \pm 1.2^{\mathrm{d}}$ & $2.1 \pm 0.2^{\mathrm{d}}$ & $3.5 \pm 0.11^{\mathrm{d}}$ & $0.40 \pm 0.13^{\mathrm{d}}$ \\
\hline EMPA 250 $\mathrm{mg} \mathrm{kg}^{-1}$ & $12.3 \pm 0.12^{\mathrm{d}}$ & $1.9 \pm 0.37^{\mathrm{d}}$ & $3.8 \pm 1.02^{\mathrm{b}}$ & $0.46 \pm 0.15^{\mathrm{d}}$ \\
\hline
\end{tabular}

Results expressed as the mean \pm SD of 5 replicas, RT: rise time, IT: intromission time, ET: ejaculation time, PEI: post-ejaculatory interval. ANOVA test treatment with Tukey's multiple comparisons test: ${ }^{\mathrm{a}} \mathrm{p}<0.01{ }^{\mathrm{b}} \mathrm{p}<0.001$ and ${ }^{\mathrm{c}} \mathrm{p}<0.0001$.

The frequencies of ascension (ND) and intromission (NI) vary between $0.03 \pm 0.01$ (EM PA 200 mg.kg-1) and $0.07 \pm 0.01$

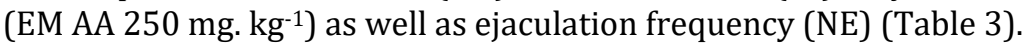

Table 3 Variation of physical parameters during the evaluation of aphrodisiac activity.

\begin{tabular}{|c|c|c|c|}
\hline Groups & ND / min & NI / min & NE / min \\
\hline NaCl 0.9\% & $0.01 \pm 0.00$ & $0.02 \pm 0.01$ & $0.02 \pm 0.01$ \\
\hline Sildenafil10 $\mathrm{mg} \mathrm{kg}^{-1}$ & $0.06 \pm 0.01^{\mathrm{a}}$ & $0.05 \pm 0.01^{\mathrm{a}}$ & $0.05 \pm 0.01^{\mathrm{a}}$ \\
\hline EAAA 200 $\mathrm{mg} \mathrm{kg}^{-1}$ & $0.07 \pm 0.02^{\mathrm{c}}$ & $0.07 \pm 0.02^{\mathrm{b}}$ & $0.06 \pm 0.01^{\mathrm{b}}$ \\
\hline EMAA 200 $\mathrm{mg} \mathrm{kg}^{-1}$ & $0.06 \pm 0.01^{\mathrm{b}}$ & $0.06 \pm 0.01^{\mathrm{a}}$ & $0.06 \pm 0.01^{\mathrm{b}}$ \\
\hline EAAA 250 $\mathrm{mg} \mathrm{kg}^{-1}$ & $0.06 \pm 0.02^{\mathrm{b}}$ & $0.06 \pm 0.01^{\mathrm{a}}$ & $0.06 \pm 0.01^{\mathrm{b}}$ \\
\hline EMAA 250 $\mathrm{mg} \mathrm{kg}^{-1}$ & $0.07 \pm 0.01^{\mathrm{c}}$ & $0.07 \pm 0.01^{\mathrm{b}}$ & $0.07 \pm 0.01^{\mathrm{c}}$ \\
\hline EAPA 200 $\mathrm{mg} \mathrm{kg}^{-1}$ & $0.03 \pm 0.01$ & $0.03 \pm 0.02$ & $0.03 \pm 0.01$ \\
\hline EMPA 200 $\mathrm{mg} \mathrm{kg}^{-1}$ & $0.03 \pm 0.01$ & $0.03 \pm 0.01$ & $0.03 \pm 0.01$ \\
\hline EAPA 250 $\mathrm{mg} \mathrm{kg}^{-1}$ & $0.06 \pm 0.01^{\mathrm{b}}$ & $0.06 \pm 0.02^{\mathrm{a}}$ & $0.04 \pm 0.01$ \\
\hline EMPA 250 $\mathrm{mg} \mathrm{kg}^{-1}$ & $0.07 \pm 0.01^{\mathrm{c}}$ & $0.06 \pm 0.01^{\mathrm{a}}$ & $0.06 \pm 0.01^{\mathrm{b}}$ \\
\hline
\end{tabular}

Results expressed as the mean \pm SD of 5 replicas, FM: ascending frequency, IF: intromission frequency, FE: ejaculation frequency. Frequencies are related to time. ANOVA test treatment with Tukey's multiple comparisons test: ${ }^{\mathrm{a}} \mathrm{p}<0.01,{ }^{\mathrm{b}} \mathrm{p}<0.001$ and ${ }^{\mathrm{c}} \mathrm{p}<0.0001$.

\subsubsection{Biochemical parameters of libido}

Overall, we observe a decrease in triglyceride levels (Figure 1a), compared to the negative control (p <0.00001) as well as an increase in cholesterol (Figure 1b) and testosterone (Figure 1c) with p $<0.001$, except for AP at $200 \mathrm{mg}^{\mathrm{kg}} \mathrm{kg}^{-1}$. The aphrodisiac index (Figure 1d), calculated for the testosterone levels and by contribution to sildenafil, considered as a positive control, is $<1$ for AP at $200 \mathrm{mg}^{-1} \mathrm{~kg}^{-1}$ and $>1$ in the rest of the extracts (Figure 1). The triglyceride levels vary

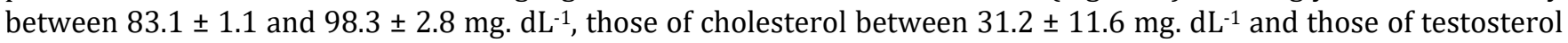
between $3.32 \pm 0,34$ and $5.11 \pm 0.19$ ng. $\mathrm{mL}^{-1}$ (Figure 1 ). 


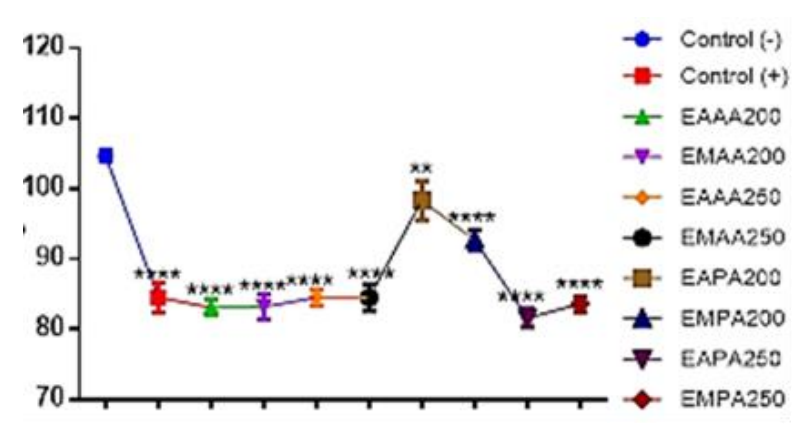

[1a] Triglyceride (mg / dL)

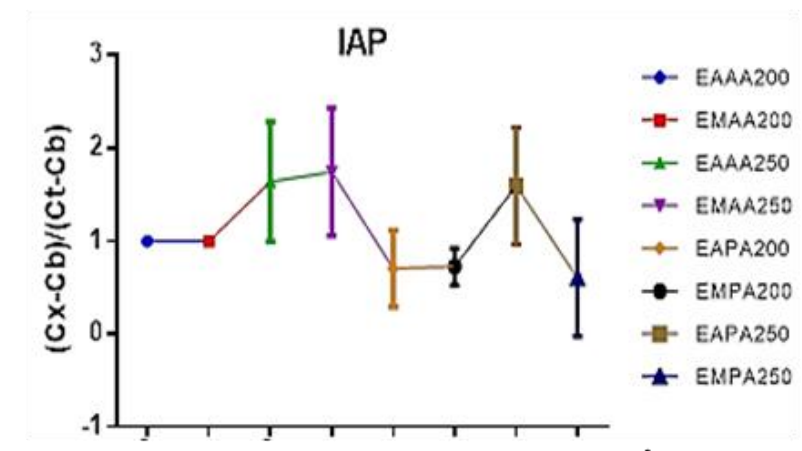

[1c] Aphrodisiac index (IAP)

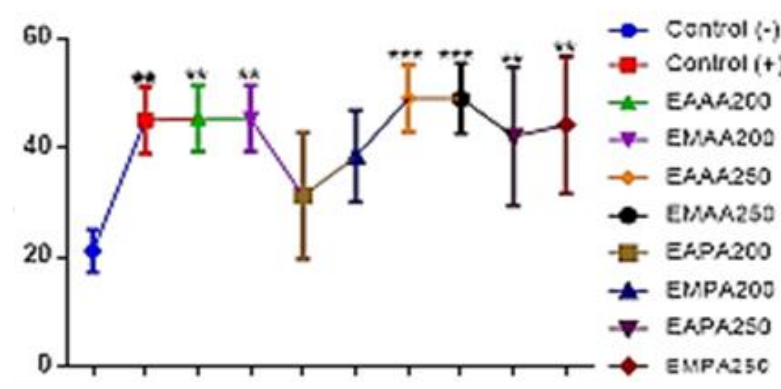

[1b] Cholesterol (mg / dL)

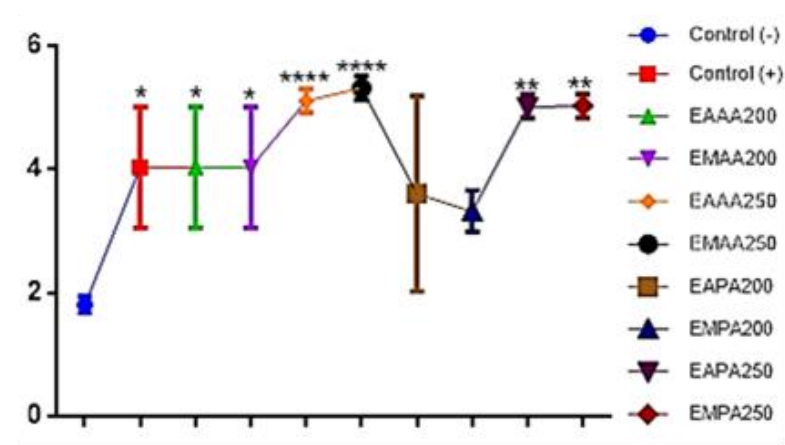

[1d] Testosterol (ng / mL)

Figure 1 Biochemical parameters measured during the evaluation of the aphrodisiac activity in Albizia adianthifolia and Pericopsis angolensis.

EA: aqueous extract, EM: methanolic extract, AA: Albizia adiathifolia, PA: Pericopsis angolensis, Control (-), NaCl 0.9\%, Control (+): Syldenafil $10 \mathrm{mg} / \mathrm{kg}$; results of mean \pm SD $\mathrm{n}=5$, statistical ANOVA treatment with Tukey's multiple comparisons test, ${ }^{*} \mathrm{p}<0.01,{ }^{* *} \mathrm{p}<0.001,{ }^{* * *} \mathrm{p}<0.0001,{ }^{* * * *} \mathrm{p}<0.00001$.

\subsection{Antioxidant activity and correlation with testosterone level}

\subsubsection{Antioxidant activity}

The antioxidant activity of the extracts, evaluated as a function of the anti-free radical activity on DPPH and expressed as $1 /$ IC50 ( $\mu \mathrm{g} . \mathrm{mL}^{-1}$ ) varies between $0.079 \pm 0.001$ and $0.204 \pm 0.001\left(\mu \mathrm{g} \mathrm{mL}^{-1}\right)$ (Figure 2a), but when it is expressed in the form of ascorbic acid equivalent per $100 \mathrm{~g}$ of extract, it varies between $15.36 \pm 0.06$ and $41.27 \pm 0.12 \mathrm{mg} \mathrm{E}$ vit $\mathrm{C} /$ $100 \mathrm{~g}$ of extract (Figure $2 \mathrm{~b}$ ). In both forms of expression, AA extracts are the more antioxidant than sildenafil $(\mathrm{p}<0.001)$ (Figure 2).

\subsubsection{Correlation between antioxidant activity and testosterone level}

A positive linear correlation with high amplitude $(\mathrm{R}=0.9996)$ is observed between the antioxidant activity and the testosterone level unlike the totals of triglycerides for which a negative and low amplitude correlation $(\mathrm{R}=0.251)$ is observed with antioxidant activity (Figure 2c and 2d). 


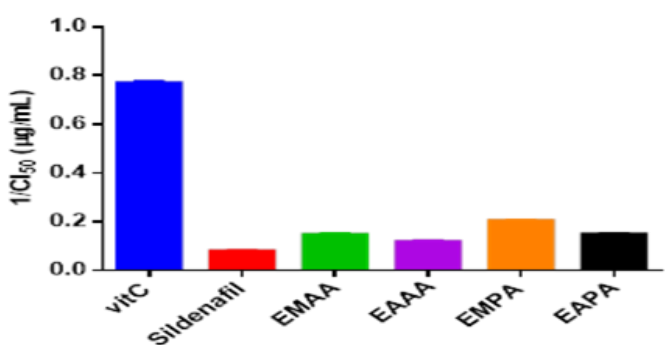

2a. Antioxidant activity expressed as $1 / \mathrm{IC}_{50}$

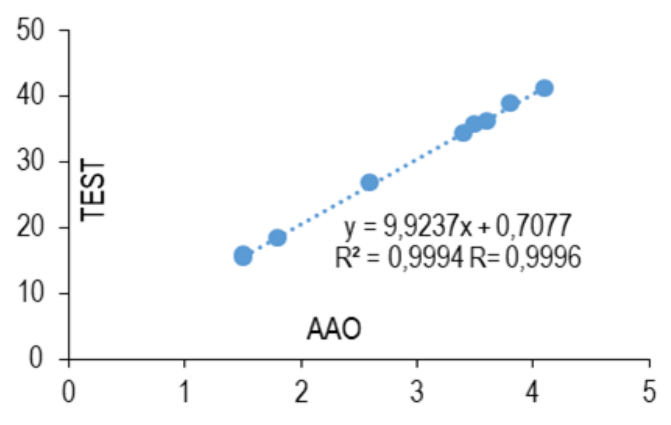

2c. Correlation between antioxidant activity (AAO) and testosterone level (TEST)

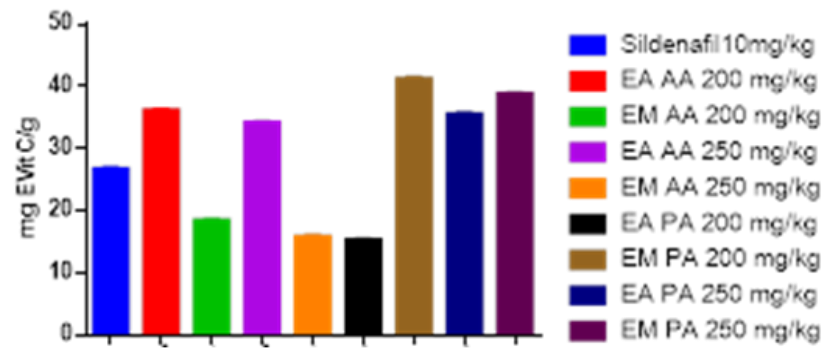

2b. Antioxidant activity expressed as ascorbic acid equivalent per $100 \mathrm{~g}$ of extracts

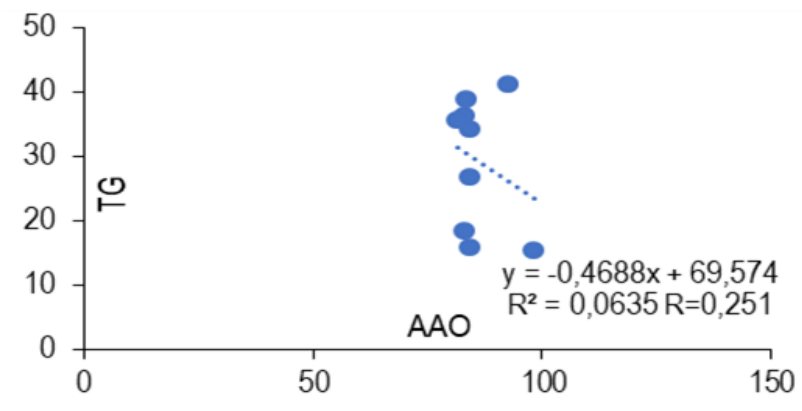

2d. Correlation between antioxidant activity (AAO) and triglyceride level (TEST)

Figure 2 Antioxidant activity and correlation antioxidant activity versus aphrodisiac activity

\section{Discussion}

During this study, we evaluated the aphrodisiac properties of aqueous and methanolic extracts of 2 plants used in traditional medicine in the commune of Kampemba in Lubumbashi-DRC, Albizia adianthifolia (Schum.) W. Wight (Fabaceae) and Pericopsis angolensis (Baker) Meeuwen (Fabaceae) [12], by examining sexual behavior and hormonal variation. The study also evaluated the antioxidant activity of the same extracts before establishing a correlation between the antioxidant activity and the aphrodisiac index.

The various observations recorded during this study reveal that the administration of doses of $200 \mathrm{mg}^{\mathrm{kg}}{ }^{-1} \mathrm{bw}$ of extract of $A$. adianthifolia modifies the physical parameters, indicators of libido on Cavia porcellus and that these effects appear to be dose dependent. "Thus", we observed a significant variation between oral administration of the doses of 200 and 250 mg.kg-1 bw $(\mathrm{p}<0.01)$. The performances induced by the oral administration of the extracts of $A$. adianthifolia consist of a decrease in time of RT, IT, PEI and an increase of ND, NI and NE frequencies, as during the oral administration of Sildenafil at $10 \mathrm{mg}$. $\mathrm{kg}^{-1} \mathrm{bw}$. Furthermore, the oral administration of $P$. angolensis shows a significant difference between the doses of 200 and $250 \mathrm{mg}$. kg-1 bw, however, these extracts behave in the same way as sildenafil. A. adianthifolia at $200 \mathrm{mg}$. $\mathrm{kg}^{-1} \mathrm{bw}$ and, $P$. angolensis at $250 \mathrm{mg}$. $\mathrm{kg}^{-1} \mathrm{bw}$ exhibit very similar aphrodisiac activity. On the other hand, the methanolic extracts exhibit a lower activity $(\mathrm{p}<0.01)$ than their aqueous extracts for $A$. adianthifolia unlike $P$. angolensis for which, no significant difference is observed. These data make it possible to understand not only why traditional medicine uses A. adianthifolia at doses equivalent to $200 \mathrm{mg}$. kg-1 bw and, P. angolensis at doses of $250 \mathrm{mg}^{-1} \mathrm{~kg}^{-1} \mathrm{bw}$ but also the need to prefer the aqueous extract of the species $A$. adianthifolia to the detriment of alcoholic extract [12]. On the other hand, for $P$. angolensis, these results suggest that the alcoholic extract is also used in the same way as the aqueous extract insofar as they could produce similar results from the point of view of physical activity the methanolic extracts exhibit a lower activity $(\mathrm{p}<0.01)$ than their aqueous extracts for $A$. adianthifolia unlike $P$. angolensis for which, no significant difference is observed. The methanolic extracts exhibit a lower activity $(\mathrm{p}<0.01)$ than their aqueous extracts for $A$. adianthifolia unlike $P$. angolensis for which, no significant difference is observed.

The literature reports that TG levels vary inversely with cholesterol and testosterone levels and serum testosterol levels increase during sexual intercourse [13-16] as a result of an olfactory stimuli leading to the activation of the hypothalamic-pituitary axis [17]. These variations were observed in the same order during this study. In addition, it has been reported that testosterone acts on the periphery by facilitating nitrergic neurotransmission, accentuating the release of nitric oxide in the cavernous bodies thus contributing to penile erection $[18,19]$. For this purpose, it constitutes a biomarker of aphrodisiac activity as observed during this study in the groups treated with sildenafil and 
the test groups (Figure 1). It is in this context that we calculated the aphrodisiac index as the ratio between the testosterone levels of the trial group and sildenafil (Figure 1c); moreover, the increase in serum cholesterol levels may be justified by the increase in serum testosterone levels since cholesterol constitutes a synthetic precursor [20] and that it increases in vitro in proportion to the levels of testosterones [21,22]. Some studies have even found a positive correlation between increased serum cholesterol levels and increased erectile function [23,24]. It could within certain limits constitute another biomarker of aphrodisiac activity in the absence of the possibility of resorting to conventional biomarkers.

A positive correlation was observed between antioxidant activity and testosterone level (Figure 2c). Previous work $[25,26]$ reported that antioxidant plants increase libido and at the same time it has been argued that flavonoids and other polyphenols have an aphrodisiac property due to their androgenic properties [27] and estrogenic [28] as well as their inhibitory action of phosphodiesterases [29]. These observations can justify the positive correlation observed during this study between aphrodisiac activity and the level of testosterones which would be due to the presence of the natural polyphenols present in the various extracts examined.

Among the compounds identified or isolated in A. adianthifolia [6], some are also found in other species known to be aphrodisiacs. This is notably the case with Aurantiamide acetate isolated from Hybanthus enneaspermus (L.) F. Muell, Violaceae [30], Octadecanoic acid identified from Sida cordata (Burm.f.) Borss.Waalk., Malvaceae [31] and Prosapogenin isolated from Tribulus terrestris L., Zygophyllaceae [32]. However, no study has so far evaluated the contribution of these compounds in the expression of the aphrodisiac activity of the aforementioned plants. It would be desirable for a further study to do so. For Pericopsis angolensis, no sophisticated phytochemical studies are reported. However, preliminary phytochemical screens performed on the species revealed flavonoids, saponins and tannins [8]. Of all these phytochemical groups, only the tannins, through protodioscin and protogracillin, isolated from Tribulus terrestris L., Zygophyllaceae are responsible of the aphrodisiac activity [33]. It would be desirable to evaluate the activity of the major groups of secondary metabolites and to determine among them the phytochemical groups with aphrodisiac property.

\section{Conclusion}

A. adianthifolia and $P$. angolensis at $200 \mathrm{mg}$. $\mathrm{kg}^{-1} \mathrm{bw}$ improve the physical parameters of libido as well as the testosterone level and to this end exhibit an aphrodisiac effect similar to their antioxidant activity. These results constitute a scientific basis likely to justify the use of these two plant species as aphrodisiacs in traditional medicine of Lubumbashi. Further studies should focus on the isolation of these antioxidant and aphrodisiac compounds preferably for P. angolensis whose phytochemistry is not reported.

\section{Compliance with ethical standards}

\section{Acknowledgments}

The authors thank the traditional healers who agreed to share their knowledge as well as Ir Dédé Mbungu of Kipopo herbarium for his collaboration in the scientific identification of plants.

\section{Disclosure of conflict of interest}

All the authors declare that they have no conflict of interest.

\section{Statement of ethical approval}

The project proposal and procedures were reviewed and approved by the Department of Pharmacology in the faculty of Pharmaceutical Sciences from the University of Lubumbashi, DR Congo (UNILU/FSP/DPCOL/PT/02/2017).

\section{Authors' contributions}

Bashige chiribagula $\mathrm{V}$ designed the study, performed the statistical analysis, wrote the protocol, and wrote the first draft of the manuscript. Alombong Alonie G, managed the execution of the protocol and the collection of data. Manya Mboni H, Bakari Amuri S and Okusa Ndjolo P managed analyzes of the study and the literature searches. All authors read and approved the final manuscript. 


\section{References}

[1] Matz EL, Terlecki R, Zhang Y, Jackson J, Atala A. Stem cell therapy for erectile dysfunction. Sex Med Rev. 2018; 1: $1-8$.

[2] Boombhi J, Eteki B, Hamadou B, Temgoua MN, Tchapmi D. Prevalence and risk factors of sexual dysfunction in patients with chronic heart failure in Yaoundé , Cameroon. Cardiol Cardiovasc Res. 2020; 4(1): 17-21.

[3] Irwin GM. Erectile dysfunction. Prim Care Clin off Pract. 2019; 46(2): 249-255.

[4] Isaiah IN, Okungbowa MA, Omorodion NT. Impact of herbal aphrodisiac Pausinytalia yohimbe ( Burantashi ) on the morphology of sperm cells in adult male wister rats and mice. Acta Sci Pharm Sci. 2020; 4(2): 1-6.

[5] Bashir F, Afrin Z. Zanjabeel (Zingiber offcinale) Transformation of culinary spice to a multi- functional medicine. J Drug Deliv Ther. 2019; 9(4S): 721-725.

[6] Maroyi A. Albizia Adianthifolia : Botany, Medicinal Uses, Phytochemistry , and Pharmacological Properties. Sci World J. 2018; 2018: 1-18.

[7] Amuri B, Maseho M, Lumbu S, Pierre D, Byanga K. Ethnobotanical survey of herbs used in the management of diabetes mellitus in Southern Katanga Area/DR Congo. Pan African Med Journal. 2018; 30: 1-13.

[8] Chingwaru C, Tanja B, Chingwaru W. Aqueous extracts of Pericopsis angolensis and Swartzia madagascariensis with high antimicrobial activities against Escherichia coli 0157, Shigella spp. and Salmonella enterica subsp. enterica (Serovar typhi). African J Biotechnol. 2019; 18(29): 831-844.

[9] Reagan-shaw S, Nihal M, Ahmad N. Dose translation from animal to human studies revisited. FASEB J. 2019; 22(3): 659-661.

[10] Erhabor JO, Idu M. Aphrodisiac potentials of the ethanol extract of Aloe barbadensis Mill . root in male Wistar rats. BMC Complement Altern Med. 2017; 17(360): 1-10.

[11] Shekhar TC, Anju G. Antioxidant Activity by DPPH Radical Scavenging Method of Ageratum conyzoides Linn. Leaves. Am J Ethnomedicine. 2014; 1(4): 244-249.

[12] Bashige CV, Alombong AG, Kamwimba MA, Bakari AS, Okusa NP. Ethnobotanical study of medicinal plants used in the treatment of sexual dysfunctions in traditional medicine in Kampemba-Lubumbashi, DR Congo. World J. Adv Res Rev. 2020; 7(3): 016-032.

[13] Rupp HA, Wallen K. Relationship between testosterone and interest in sexual stimuli : The effect of experience. Horm Behav. 2007; 52: 581-589.

[14] Riocerezo CP, Alvarez S, Abecia JA, Martin-Gil J. Plasma hormonal levels of rams are affected by sexual activity and Confinement in a Semen Collection Centre. ARC J Anim Vet Sci. 2016; 2(2): 15-21.

[15] Kisserli 0, Moudilou E, Exbrayat J. Sexual cycle and seasonal expression of testosterone ( $\mathrm{T}$ ) in the testes of Sclerophrys Sexual cycle and seasonal expression of testosterone ( Schlegel , 1841 ). African J Herpetol. 2017; 66(2): 106-121.

[16] Gani F, Niar A. Seasonal Changes In Plasma Levels Of FSH, LH, And Testosterone In Local Rams Raised. Curr Trends Nat Sci. 2019; 8(16): 109-116.

[17] Tejada LD, Rissman EF. Sex Differences in Social Investigation : Effects of androgen receptors, hormones and test partner neuroendocrinology. J Neuroendocrinol. 2012; 21(1): 1144-1153.

[18] Isidori AM, Buvat J, Corona G, Goldstein I, Jannini EA, Lenzi A, et al. A Critical Analysis of the Role of Testosterone in Erectile Function : From Pathophysiology to Treatment - A Systematic Review. Eur Urol. 2014; 65(1): 99112.

[19] Swelum AA, Saadeldin IM, Zaher HA, Alshari SAM, Alowaimer AN. Effect of sexual excitation on testosterone and nitric oxide levels of water buffalo bulls (Bubalus bubalis) with different categories of sexual behavior and their correlation with each other. Anim Reprod Sci. 2017; 181(6): 151-158.

[20] Meikle AW, Sousa JCC De, Hanzalova J, Murray DK. Oleic Acid Inhibits Cholesteryl Esterase and Cholesterol Utilization for Testosterone Synthesis in Mouse Leydig Cells. Metabolism. 1996; 45(3): 293-299.

[21] Hou JW, Collins DC, Schleicher RL. Sources of Cholesterol for Testosterone Biosynthesis in Murine Leydig Cells . Endocrinology. 1990; 127(5): 2047-2055. 
[22] Sambyal K, Singh RV. Production aspects of testosterone by microbial biotransformation and future prospects. Steroids. 2020; 159(6): 108651.

[23] Saltzman EA, Guay AT, Jacobson J. Improvement in erectile function in men with organic erectile dysfunction by correction of elevated cholesterol levels : A Clinical Observation. J Urol. 2004; 172(1): 255-258.

[24] Koyuncu HH, Guzel O, Memis ALI. Effect of correcting serum cholesterol levels on erectile function in patients with vasculogenic erectile dysfunction. Scand J Urol Nephrol. 2008; 42(10): 42-45.

[25] Sparman A, Thompson K. Safety Profile and Effect on Libido of a Combined Bryophyllum pinnatum , and Vitamin C Phytotherapeutic Agent. Free Radicals Antioxidants. 2017; 7(2): 156-159.

[26] Riaz M, Shahid M, Jamil A, Saqib M. In vitro antioxidant potential of selected aphrodisiac medicinal plants. J Biol Regul Homeost Agents. 2017; 31(2): 419-424.

[27] Nishizaki Y, Ishimoto Y, Hotta Y, Hosoda A, Yoshikawa H. Effect of flavonoids on androgen and glucocorticoid receptors based on in vitro reporter gene assay. Bioorg Med Chem Lett. 2009; 19(16): 4706-4710.

[28] Resende A, Oliveira APS De, Camargo MS De, Vilegas W. Evaluation of estrogenic potential of flavonoids using a recombinant yeast strain and MCF7 / BUS Cell Proliferation Assay. PLoS One. 2013; 8(10): 1-7.

[29] Ko W, Shih C, Lai Y, Chen J, Huang H. Inhibitory effects of flavonoids on phosphodiesterase isozymes from Guinea pig and their structure - activity relationships. Biochem Pharmacol. 2004; 68: 2087-2094.

[30] Patel DK, Kumar R, Sairam K, Hemalatha S. Hybanthus enneaspermus (L.) F. Muell: A concise report on its phytopharmacological aspects. Chin J Nat Med. 2013; 11(3): 199-206.

[31] Ganesh M, Mohankumar M. Extraction and identification of bioactive components in Sida cordata (Burm.f.) using gas chromatography-mass spectrometry. J Food Sci Technol. 2017; 54(10): 3082-3091.

[32] Semerdjieva IB, Zheljazkov VD. Chemical constituents, biological properties, and uses of Tribulus terrestris: A Review. Nat Prod Commun. 2019; 14(8): 1-26.

[33] Chhatre S, Nesari T, Somani G, Kanchan D, Sathaye S. Phytopharmacological overview of Tribulus terrestris. Pharmacogn Rev. 2014; 8(15): 45-51. 